\title{
Mapping Bedrock Surface Contours Using the Horizontal- to-Vertical Spectral Ratio (HVSR) Method Near the Middle Quarter Area, Woodbury, Connecticut
}

The bedrock surface contours in Woodbury, Connecticut, were determined downgradient of a commercial zone known as the Middle Quarter area (MQA; fig. 1) using the novel, noninvasive horizontal-to-vertical (H/V) spectral ratio (HVSR) passive seismic geophysical method. Boreholes and monitoring wells had been drilled in this area to characterize the shallow subsurface to within 20 feet (ft) of the land surface, but little was known about the deep subsurface, including sediment thicknesses and depths to bedrock (Starn and Brown, 2007; Brown and others, 2009). Improved information on the altitude of the bedrock surface and its spatial variation was needed for assessment and remediation of chlorinated solvents that have contaminated the overlying glacial aquifer that supplies water to wells in the area.

Depth to bedrock near the MQA was first determined using the HVSR method, which uses three-component seismometers to record the ambient seismic noise, such as that induced by distant weather or ocean waves impacting the shore. In areas that have a strong acoustic impedance contrast between the bedrock and overlying sediments, such as near the MQA, the seismic noise induces resonance at frequencies in the range of about 0.1 to 100 hertz. The ratio of the average horizontaland vertical-component amplitude spectrums produces a spectral ratio curve with peaks at fundamental and higher order resonance frequencies. Resonance frequencies are a function of both sediment layer thickness and average layer shearwave velocity.

Measurements were made along several transects downgradient of the MQA (fig. 1) using the field methods described in Lane and others (2008). Additional measurements were collected at several surrounding bedrock wells where the altitude of the bedrock surface is known. These were used to calculate a local regression line based on the relationship between the sediment thickness $(z)$ and the resonance frequency $\left(f_{r}\right.$; in hertz) of the main peak in $\mathrm{H} / \mathrm{V}$ spectra:

$$
z=a f_{r}^{-b}
$$

where

$a$ and $b \quad$ are empirically derived coefficients (Ibs-von Seht and Wohlenberg, 1999).

Once calculated, the local regression line was used to determine sediment thickness from observed frequencies within the same geologic framework. The values for $a$ (209.17) and $b(0.798)$ were determined from the observed resonance frequencies and corresponding depths to bedrock (table 1; fig. 2) at six well locations around the MQA. Using these values for a and $\mathrm{b}$, the depth of the bedrock ( $y$; in feet) is calculated to be:

$$
y=209.17 f_{r}^{-0.798} .
$$

Once the depths to bedrock were calculated using the local regression, bedrock altitude was determined by subtracting the depths determined from a 2-ft contour light detection and ranging (LiDAR) digital elevation model (State of Connecticut, 2011) or from land-surface altitudes previously surveyed at monitoring wells; these bedrock altitudes and regional-scale studies of the bedrock surface (Starn and Brown, 2007; Burton, 2011) constrained by bedrock outcrops and drilling logs from domestic wells were used to draw bedrock altitude contours (fig. 3).

The bedrock-surface contour map shows a high area to the southwest of the MQA within a larger bedrock valley. The bedrock surface could affect the movement of dense nonaqueous phase liquids (DNAPLs) in the glacial aquifer. The modeled bedrock surface provides a tool to help target drilling locations for characterization of DNAPL contaminants in the source area. 


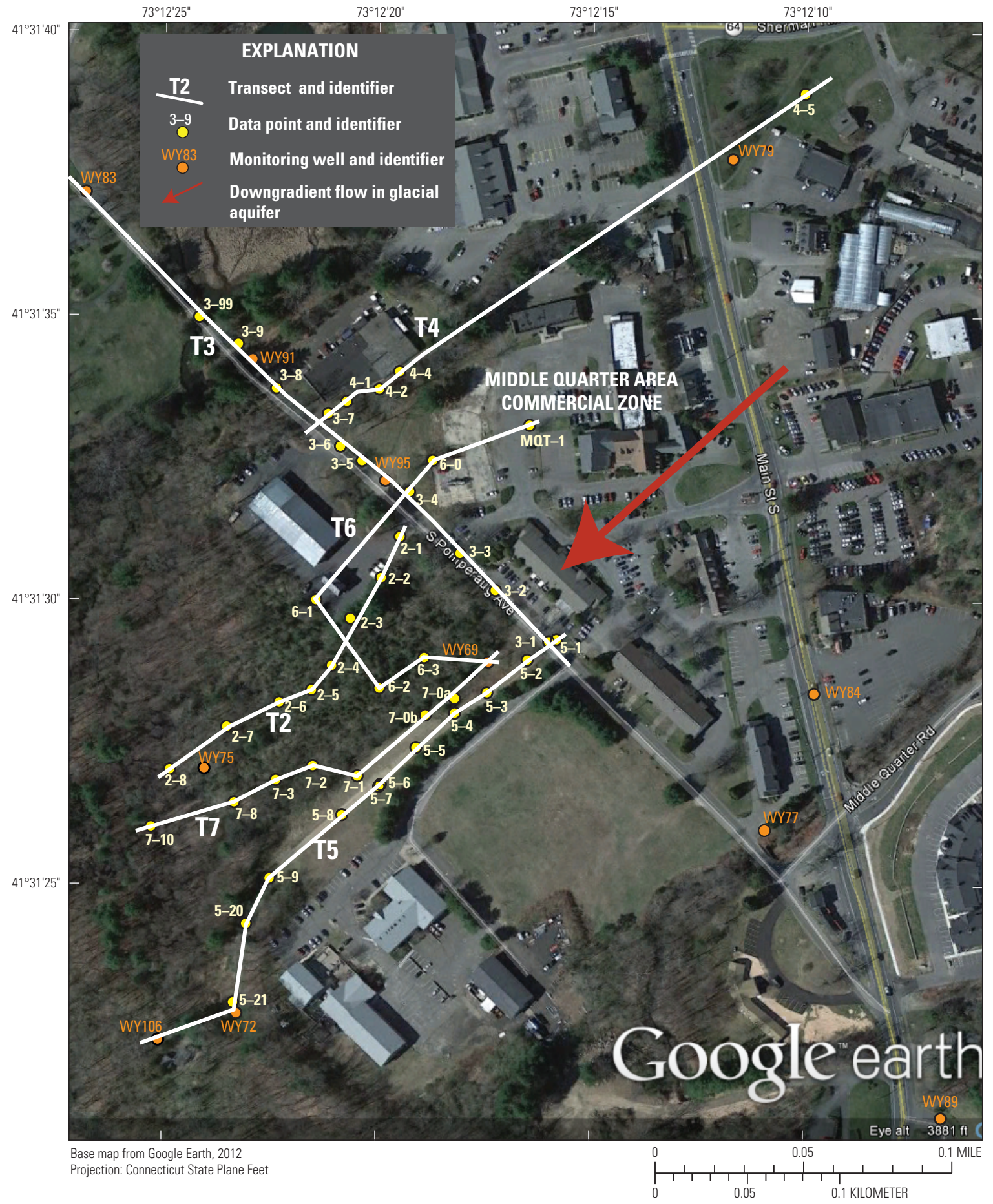

Figure 1. Aerial photograph of study area showing locations of seismometer readings, the study transects, and the monitoring wells in Woodbury, Connecticut.

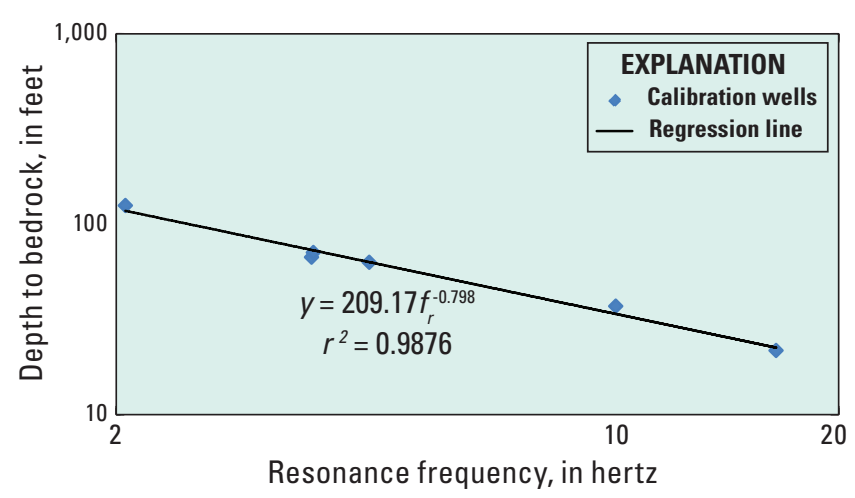

Figure 2. Regression plot and line equation for resonance frequency and depth to bedrock in Woodbury, Connecticut. $\left(f_{r}\right.$, resonance frequency; $r^{2}$, coefficient of determination; $y$, depth to bedrock). 
Table 1. Resonance frequencies and estimated bedrock depths and altitudes for seismometer reading sites and calibration wells in Woodbury, Connecticut.

[NAVD 88, North American Vertical Datum of 1988, in feet]

\begin{tabular}{|c|c|c|c|c|c|c|c|}
\hline $\begin{array}{l}\text { Seismometer } \\
\text { reading sites }\end{array}$ & $\begin{array}{l}\text { Resonance } \\
\text { frequency, } \\
\text { in hertz }\end{array}$ & $\begin{array}{c}\text { Estimated } \\
\text { bedrock depth, } \\
\text { in feet }\end{array}$ & $\begin{array}{l}\text { Estimated } \\
\text { bedrock } \\
\text { altitude, } \\
\text { in feet } \\
\text { (NAVD 88) }\end{array}$ & $\begin{array}{l}\text { Seismometer } \\
\text { reading sites }\end{array}$ & $\begin{array}{l}\text { Resonance } \\
\text { frequency, } \\
\text { in hertz }\end{array}$ & $\begin{array}{c}\text { Estimated } \\
\text { bedrock depth, } \\
\text { in feet }\end{array}$ & $\begin{array}{l}\text { Estimated } \\
\text { bedrock } \\
\text { altitude, } \\
\text { in feet } \\
\text { (NAVD 88) }\end{array}$ \\
\hline $2-1$ & 4.16 & 67.1 & 161.4 & $7-10$ & 4.41 & 64.0 & 151.5 \\
\hline $2-2$ & 4.36 & 64.6 & 164.3 & WY83 & 8.16 & 39.2 & 206.2 \\
\hline $2-3$ & 5.28 & 55.4 & 174.0 & WY84 & 4.92 & 58.7 & 184.1 \\
\hline $2-4$ & 5.63 & 52.7 & 176.6 & WY931 & 7.28 & 42.9 & 208.7 \\
\hline $2-5$ & 6.04 & 49.8 & 179.4 & WY75 & 4.09 & 68.0 & 150.5 \\
\hline $2-6$ & 5.45 & 54.1 & 175.4 & \multirow{3}{*}{$\begin{array}{c}\text { Calibration } \\
\text { well }\end{array}$} & \multirow{3}{*}{$\begin{array}{l}\text { Resonance } \\
\text { frequency, } \\
\text { in hertz }\end{array}$} & \multirow{3}{*}{$\begin{array}{l}\text { Bedrock depth, } \\
\text { in feet }\end{array}$} & \multirow{3}{*}{$\begin{array}{l}\text { Bedrock } \\
\text { altitude, } \\
\text { in feet } \\
\text { (NAVD 88) }\end{array}$} \\
\hline $2-7$ & 4.42 & 63.9 & 160.1 & & & & \\
\hline $2-8$ & 4.06 & 68.4 & 147.3 & & & & \\
\hline $3-1$ & 3.45 & 77.9 & 152.0 & \multirow{2}{*}{ WY69 } & 3.73 & 66.9 & 166.3 \\
\hline $3-2$ & 3.48 & 77.3 & 153.2 & & 4.48 & 63.0 & 175.1 \\
\hline $3-3$ & 3.94 & 70.0 & 160.2 & WY89 & 9.83 & 37.1 & 226.0 \\
\hline $3-4$ & 3.98 & 69.5 & 158.3 & WY98 ${ }^{1}$ & 16.39 & 21.7 & 230.6 \\
\hline $3-5$ & 4.22 & 66.3 & 159.5 & \multirow{2}{*}{ WY106 } & 3.75 & 70.9 & 148.9 \\
\hline $3-6$ & 4.27 & 65.7 & 160.8 & & 2.06 & 125.0 & 140.0 \\
\hline $3-7$ & 4.31 & 65.2 & 161.3 & ${ }^{1}$ Outside of the & a shown in figu & & \\
\hline $3-8$ & 3.81 & 71.9 & 155.1 & Roforoncoc & and & & \\
\hline $3-9$ & 4.31 & 65.2 & 162.9 & References & ted & & \\
\hline $3-99$ & 4.73 & 60.5 & 168.2 & Brown, C.J., S & n, J.J., Stoll & werk, K.G., Mon & zzi, R.A., \\
\hline $4-1$ & 3.39 & 79.0 & 147.0 & and Tromble & T.J., 2009, & uifer chemistry & transport \\
\hline $4-2$ & 3.25 & 81.7 & 145.1 & processes in & e zone of co & ribution to a pub & -supply well \\
\hline $4-4$ & 3.22 & 82.3 & 146.2 & in Woodbury & Connecticut, & 002-06: U.S. Ge & ogical Survey \\
\hline $4-5$ & 2.73 & 93.8 & 144.4 & Scientific In & stigations R & ort 2009-5051, & p. \\
\hline $5-1$ & 3.47 & 77.5 & 152.8 & $\begin{array}{l}\text { http://pubs.u } \\
\text { Burton, W.C., }\end{array}$ & $\begin{array}{l}\text { S.gov/sir/20 } \\
06, \text { Bedrock }\end{array}$ & $\begin{array}{l}/ 5051 / . \\
\text { eologic map of tl }\end{array}$ & early \\
\hline $5-2$ & 3.63 & 74.8 & 158.0 & Mesozoic P & peraug basil & surrounding base & ent rocks, \\
\hline $5-3$ & 3.81 & 71.9 & 161.3 & Litchfield an & New Haven & Dunties, Connect & t: U.S. \\
\hline $5-4$ & 3.80 & 72.1 & 160.8 & Geological & rvey Open F & Report 2006-10 & , 1 sheet, \\
\hline $5-5$ & 3.86 & 71.2 & 160.4 & http://pubs.u & s.gov/of/20c & /1011/. & \\
\hline $5-6$ & 3.80 & 72.1 & 159.4 & Ibs-von Seht, I & lte, and Wol & enberg, Jürgen, 1 & \\
\hline $5-7$ & 3.75 & 72.8 & 158.6 & $\begin{array}{l}\text { Microtremo } \\
\text { sediments: } \mathrm{F}\end{array}$ & $\begin{array}{l}\text { heasurement } \\
\text { lletin of the }\end{array}$ & $\begin{array}{l}\text { used to map thick } \\
\text { ismological Soci }\end{array}$ & $\begin{array}{l}\text { ess of soft soil } \\
\text { y of America. }\end{array}$ \\
\hline $5-8$ & 3.52 & 76.6 & 153.0 & v. 89 , no. 1 , & $250-259$ & & \\
\hline $5-9$ & 3.59 & 75.4 & 149.7 & Lane, J.W., Jr., & hite, E.A., S & ele, G.V., and Car & a, J.C., 2008, \\
\hline $5-20$ & 3.44 & 78.0 & 140.5 & Estimation o & edrock dept & using the horizon & -to-vertical \\
\hline $5-21$ & 3.47 & 77.5 & 137.9 & $(\mathrm{H} / \mathrm{V})$ ambie & -noise seism & method, in Symp & ium on the \\
\hline $6-0$ & 3.06 & 85.7 & 143.5 & Application & Geophysics & Engineering and & nvironmental \\
\hline $6-1$ & 3.17 & 83.3 & 145.4 & $\begin{array}{l}\text { Problems, A } \\
\text { Proceedings }\end{array}$ & $\begin{array}{l}16-10,2008 \\
\text { enver, Color }\end{array}$ & $\begin{array}{l}\text { Philadelphia, Pen } \\
\text { do, Environmenta }\end{array}$ & $\begin{array}{l}\text { ylvania, } \\
\text { and }\end{array}$ \\
\hline $6-2$ & 3.75 & 72.8 & 159.5 & $\begin{array}{l}\text { Proceedings } \\
\text { Engineering }\end{array}$ & eophysical S & iety, 13 p., http:// & ater.usgs.gov/ \\
\hline 6-3 & 3.70 & 73.6 & 157.1 & ogw/bgas/pu & ications/SAC & EP2008-Lane_H & \\
\hline MQT-1 & 3.17 & 83.3 & 146.6 & Starn, J.J., and & rown, C.J., 2 & 07, Simulations & ground- \\
\hline $7-0 \mathrm{a}$ & 3.72 & 73.3 & 159.4 & water flow a & residence ti & e near Woodbury & Connecticut: \\
\hline $7-0 \mathrm{~b}$ & 3.77 & 72.5 & 159.3 & U.S. Geolog & al Survey Sc & ntific Investigati & s Report \\
\hline $7-1$ & 3.93 & 70.2 & 160.4 & 2007-5210, & p. & ecticut $2 \mathrm{ft}$ contol & eviced). \\
\hline $7-2$ & 4.08 & 68.1 & 161.9 & Hartford, Co & ecticut, State & f Connecticut, De & tment of \\
\hline $7-3$ & 4.19 & 66.7 & 161.1 & Environment & Protection, $\mathrm{h}$ & ://www.cteco.uco & l.edu/metadata/ \\
\hline $7-8$ & 4.19 & 66.7 & 155.1 & & CONTOUR & 000 2FT_FGDC & us.htm. \\
\hline
\end{tabular}




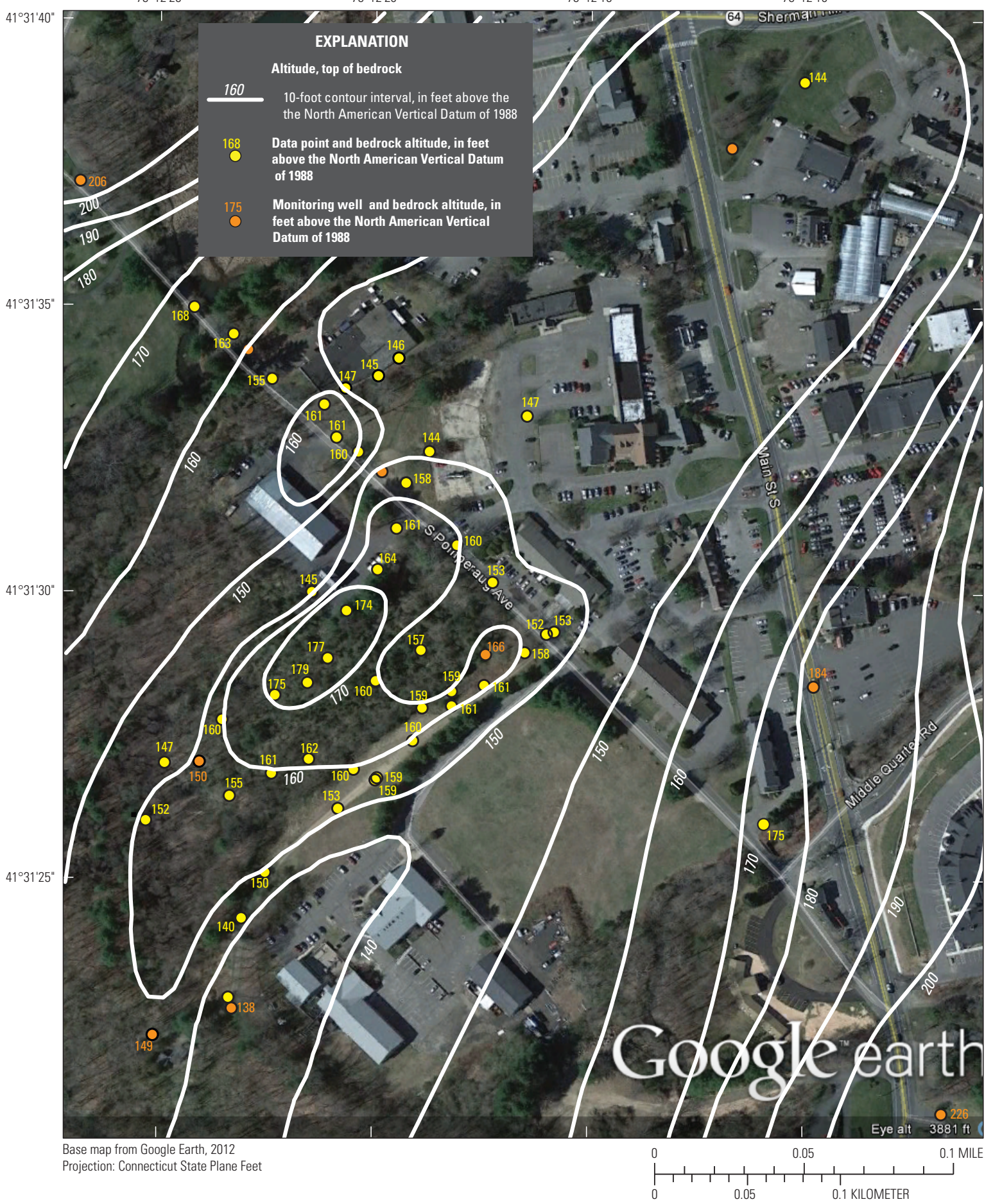

Figure 3. Aerial photograph of the study area showing locations of seismometer readings, monitoring wells, and the bedrock altitudes and contours in Woodbury, Connecticut. NAVD 88, North American Vertical Datum of 1988.

For more information on the USGS - the Federal source for science about the Earth, its natural and living resources, natural hazards, and the environment, visit http://www.usgs.gov/ or call 1-888-ASK-USGS.
For an overview of USGS information products, including maps, imagery, and publications,

visit http://www.usgs.gov/pubprod/.

To order this and other USGS information products, visit http://store.usgs.gov/.
For more information, contact:

Craig Brown

New England Water Science Center Connecticut Office

101 Pitkin St

East Hartford, CT 06108

Telephone: 860-291-6766

Email: cjbrown@usgs.gov 